\title{
Biomass Distribution and Development of Allometric Equations for Non-Destructive Estimation of Carbon Sequestration in Grafted Mango Trees
}

\author{
A. N. Ganeshamurthy ${ }^{1}$, V. Ravindra ${ }^{1}$, R. Venugopalan ${ }^{1}$, Malarvizhi Mathiazhagan $^{1} \&$ R. M. Bhat $^{1}$ \\ ${ }^{1}$ Indian Institute of Horticultural Research, Hessaraghatta Lake Post, Bengaluru, India \\ Correspondence: A. N. Ganeshamurthy, Division of Soil Science, Indian Institute of Horticultural Research, \\ Hessaraghatta Lake Post, Bengaluru 560089, India. Tel: 91-944-981-6282. Fax: 91-802-844-6649. E-mail: \\ angmurthy@gmail.com
}

Received: January 4, 2016

Accepted: March 3, $2016 \quad$ Online Published: July 15, 2016

doi:10.5539/jas.v8n8p201

URL: http://dx.doi.org/10.5539/jas.v8n8p201

\begin{abstract}
The general equations available/developed for forest/wild mango trees based on measurement of diameter at breast height (DBH) (cannot be used) are not applicable for mango orchards which are predominantly established with grafted plants. Hence allometric equations were developed with destructive sampling of grafted mango trees. The selected parameters showed that allometric parameters were significantly related with age of the trees. The proportion of roots $(22 \%)$ in grafted mangos was found to be higher than those reported for tropical forest trees $(18 \%)$ with a $\mathrm{R}$ ratio of 0.291 . The biomass expansion factor (BEF) varied with age. Initially the BEF was very high followed by a decreasing phase and finally a steady phase by and large attained stability beyond 20 years. The equations generally fitted the data well, and in most cases more than $50 \%$ of the observed variation in biomass was explained by primary branch girth $(\mathrm{PBG}) \times$ number of primary branches $(\mathrm{NPB})$. All equations were statistically significant $(\mathrm{p}<0.05)$ for both scaling parameters, $a$ and $b$. Based on the $\mathrm{R}^{2}$ values the best fit model for estimation of above ground biomass of grafted mango trees is a power model using PBG $\times$ NPB as the best dimension: There was a good agreement between the observed and the predicted biomass using this equation.
\end{abstract}

Keywords: allometric equation, biomass expansion factor, grafted trees, mango

\section{Introduction}

Non-destructive estimates of tree biomass are essential for several purposes. For example, it is essential in assessing forest structure and conditions (Westman \& Rogers, 1977); estimating forest productivity and carbon fluxes (Chambers et al., 2001); for sequestration of carbon in wood, leaves, and roots (Specht \& West, 2003); for estimating carbon sequestration and for assessing site productivity. All these depend on sequential changes in biomass.

Tree allometry is a statistical tool to relate some fairly easy to measure parameters of trees like DBH to such parameters which are often more difficult to assess. To obtain such relationships detailed measurements on a small sample of typical trees are made and then relationships are worked out such that they permit extrapolations and estimations of a host of dendrometric quantities on the basis of a single (or at most a few) measurements. This approach eases out difficult field work and enhances the speed of data collection and estimating tree biomass. This approach is very commonly practiced in forestry, but the same is not true in perennial horticulture. The data base in perennial horticulture are very poor to develop allometric relationship that relate, if any, existing between the parts of the subject measured and the quantities of parameters of interest (Smith \& Brand, 1983). This should also take in to account the factors which affect tree growth such as age, species, site location, etc. (Avery \& Burkhart, 2002). Once all these guidelines are met, one may attempt to develop an allometric equation.

In forestry many attempts have been made to develop biomass-prediction equations from mixtures of tropical species. But use of such relationships are not successful because the species especially dicotyledonous trees differ in allometry, wood density, and architecture, all of which can affect the relationship between the measurements taken during forest inventories and the biomass of individual trees (e.g., Chambers et al., 2001; Ketterings et al., 2001; Chave et al., 2005). 
Multiple species equations may help in generating large-scale global and regional estimates for comparisons. However, application of the same to particular species on specific sites in perennial horticulture is of limited utility. Such equations typically include only DBH and exclude small trees, fruit crop species, and measurements of total height. Thus, the pooled-species approach is not practically useful in perennial horticulture.

The general equations available/developed for forest/wild mango trees is based on measurement of DBH for trees/poly embryonic varieties grown from seeds. These equations cannot be used for mango orchards as commercial mango orchards are established with grafted seedlings. Grafted trees branch just above the graft union as shown in Figure 1. In such trees measurement of DBH is not practically possible. Hence we attempted to develop allometric equations for the estimation of biomass of grafted mango trees by adopting destructive sampling.

The primary objective of this study was to contribute nationally through specific data, by destructive analysis of both above- and below ground biomass pools of commercially grown orchard mangos, the major fruit tree species of India, to aid in the improvement of India's greenhouse gas (GHG) inventory reporting.
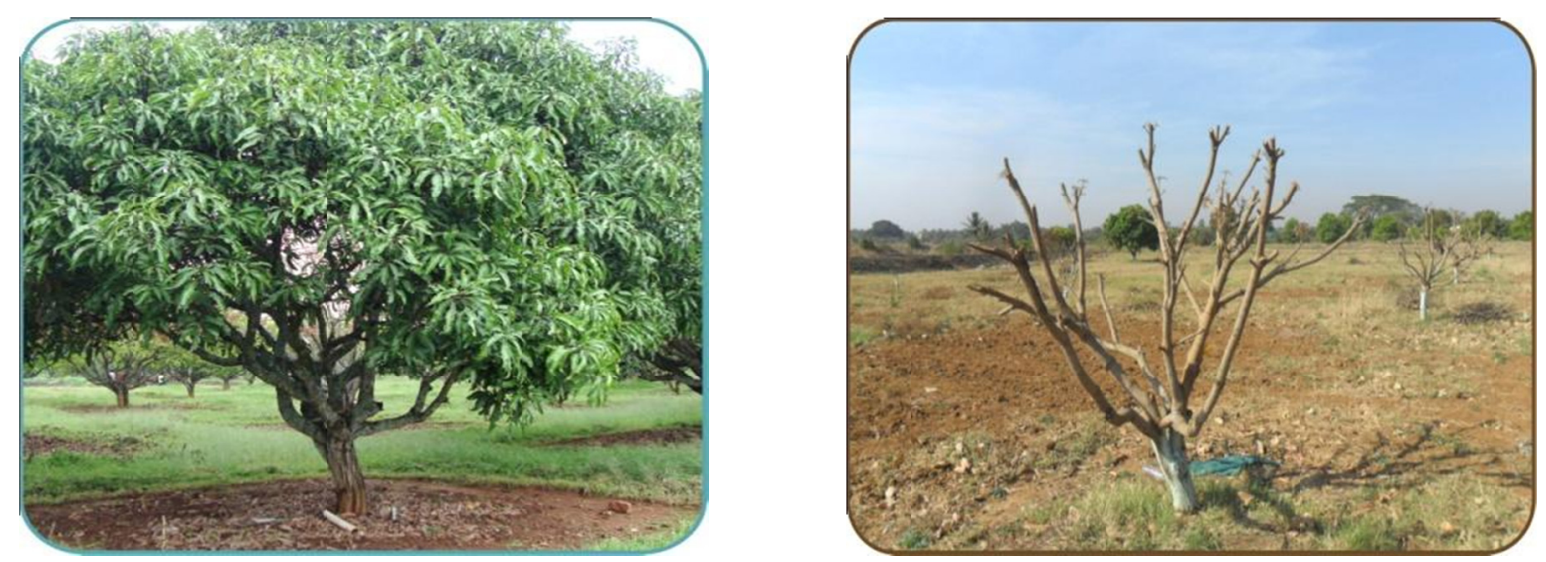

Figure 1. Showing the branching of grafted mango tree just above graft union

\section{Materials and Methods}

\subsection{Location}

The experimental sites were located at the main research farm of the ICAR-Indian Institute of Horticultural Research, Hessaraghatta, Bengaluru. It is situated in the South-Deccan plateau in peninsular India to the South-Eastern corner of Karnataka State between the latitudinal parallels of $12^{\circ} 39^{\prime} \mathrm{N}$ and $13^{\circ} 18^{\prime} \mathrm{N}$ and longitudinal meridians of $77^{\circ} 22^{\prime} \mathrm{E}$ and $77^{\circ} 52^{\prime} \mathrm{E}$ at an average elevation of about 900 meters. The climate of the area is classified as "seasonally dry tropical savanna climate with four seasons". The dry season with clear bright weather is from December to February with summer from March to May, followed by the southwest monsoon season from June to September, while October and November constitute the northeast monsoons or retreating southwest monsoon season. The main features of the climate of this region are the agreeable range of temperatures, from the highest mean maximum of $33{ }^{\circ} \mathrm{C}$ in April to the lowest mean minimum of $14{ }^{\circ} \mathrm{C}$ in January. The two rainy seasons, June to September and October to November, follow one after the other but with opposite wind regimes, corresponding to the southwest and northeast monsoons.

\subsection{Selection of Trees}

Seventy-four mango trees varying in age groups from 3 years to 85 years were identified for destructive sampling. The number of trees was 21 trees between 3 to 6 years, 21 trees between 6 to 10 years, 21 trees between 10 to 25 years and 11 trees beyond 25 years age.

\subsection{The Soil}

All these mango trees were located within a 50 ha. Areaon a fairly levelled land.The soil of the study site is an Alfisol, well drained and medium depth, silty clay loam and acidic in nature (pH 6.2). 


\subsection{Allometric Measurements}

Allometric parameters such as number of primary and secondary branches, girth of primary and secondary branches, tree height, tree volume, basal diameter, diameter below graft union (DBGU), were measured on 74 randomly selected mango trees of different age groups: 3, 5, 8, 10, 12, 15, 16, 20, 45 and 85-year-old. Stem diameter (below graft union) was measured with a diameter tape. The height of the tree and the diameter of the crown were measured with a Spiegel relaskop.

\subsection{Tree Harvesting}

Trees were measured for all allometric parameters and felled. The harvested biomass was segregated into foliage, Stem \& primary branches and secondary branches. The foliage, branches and small stem were weighed separately, taking a subsample to obtain dry matter content $\left(60{ }^{\circ} \mathrm{C}\right)$. Wood samples were taken to estimate specific gravity. Biomass was estimated based on volume and specific gravity. Total aboveground biomass was calculated as the sum of the biomass of all components.

\subsection{Biomass Expansion Factor (BEF)}

The BEF was calculated as the ratio of the biomass tothe volume, resulting in a dimensional variable $\left(\mathrm{Mg} \mathrm{m}^{-3}\right)$ :

$$
\mathrm{BEF}=\mathrm{W} / \mathrm{V}=\rho \mathrm{BEF}^{\prime}
$$

Where, $\mathrm{W}$ is the stand biomass $\left(\mathrm{Mg} \mathrm{ha}^{-1}\right), \rho$ is the dry matter basic wood density $\left(\mathrm{Mg} \mathrm{m}^{-3}\right)$ and $\mathrm{V}$ is the stand volume $\left(\mathrm{m}^{3} \mathrm{ha}^{-1}\right)$ (Soares \& Tome, 2012).

\subsection{Statistical Modelling}

Logistic Model: the rate of growth of population size is given by a model represented by the differential equation:

$$
\frac{d N}{d t}=r N\left(1-\frac{N}{K}\right)
$$

Where, $N(\mathrm{t})$ denotes the population size or biomass at time $t$ and $r$ is the intrinsic growth rate.

Integrating, we get,

$$
N_{t}=\frac{\mathrm{K}}{\left[1+\left(\frac{\mathrm{K}}{\mathrm{N}}-1\right) e^{-r t}\right]}
$$

Gompertz Model: Unlike the logistic model, this is not symmetric about its point of inflexion. The differential equation for this model is,

$$
\frac{d N}{d t}=r N \log _{\mathrm{e}}\left(\frac{\mathrm{K}}{N}\right)
$$

Integration of this equation yields,

$$
N_{(\mathrm{t})}=\mathrm{K}_{\mathrm{e}}^{\left[\log _{\mathrm{e}} \frac{N_{0}}{K} e^{-r t}\right]}
$$

The equation may equally return as,

$$
Y_{t}=C \times e^{\left(-b \times e^{-a t}\right)}+e, b=\ln \left(\frac{c}{Y_{0}}\right)
$$

Power Model: A model represented by an equation,

$$
Y_{t}=\mathrm{a} X_{\mathrm{t}}^{b}+\varepsilon
$$

As all these three models are a class of nonlinear regression model, as the derivatives of $Y_{t}$ with respect to unknown parameters are functions of either of them, suitable nonlinear estimation procedure was followed for parameter estimation (Venugopalan \& Shamasundaran, 2003). SAS codes were developed to fit these non-linear regression models.

\section{Results and Discussion}

\subsection{Component Biomass Distribution}

Stem wood in grafted plants is very low as the tree branches from the ground just above the graft union. Hence stem and primary branches were combined for calculating the biomass distribution. The majority of the aboveground biomass constituted stem and primary branch wood with dry weight on an average representing, $49.82 \%$ of the total (Table 1). Secondary branch wood and foliage accounted for a further 17.02 and $10.62 \%$, respectively. The belowground biomass accounted for the remaining $22.54 \%$ (i.e. small, medium and large roots). 
Stem and primary branches accounted for the largest proportion of the total aboveground biomass by weight (49.82\%). and was fairly similar to those reported earlier (Normand et al., 2007; Normand \& Lauri, 2012; Eneji et al., 2013). This component was $47.9 \%$ in young plants and showed an increasing trend with age and crossed $50 \%$ after 20 years. The proportion of Secondary branch wood showed a declining trend with age and declined from $21 \%$ in young plants to $15.6 \%$ at $45^{\text {th }}$ year of age. One of the reasons for this may be the practice of pruning the secondary branches for ease of management. Contrary to this the foliage biomass showed a marginal increasing trend up to 20 years and declined slightly beyond this age. The proportion of roots $(22 \%)$ was found to be higher than those reported for tropical forest trees $(18 \%)$. The general above ground to below ground ration reported for tropical forest trees is 0.26 (Cairns et al., 1997) while we found it to be 0.29 in this study. Grafting, planting density and differences in site conditions like micro climate, soil and management would account for these slight variations in the biomass distribution between the studies. Further our interest was to extract maximum possible portion of the roots from soil profiles as our aim was to work out the carbon sequestration rather than from other commercial objectives of wood as in case of forestry studies.

Table 1. Component dry weight (Kgs) of harvested mango trees of different age (data in the parenthesis represents \%)

\begin{tabular}{lllllll}
\hline $\begin{array}{l}\text { Tree Age } \\
\text { (years) }\end{array}$ & $\begin{array}{l}\text { Main Stem and } \\
\text { Primary Branches }\end{array}$ & $\begin{array}{l}\text { Secondary } \\
\text { Branches }\end{array}$ & Foliage & $\begin{array}{l}\text { Total above Ground } \\
\text { Biomass (kg) }\end{array}$ & Roots (kg) & Total (kg) \\
\hline 3 & $10.77(47.93)$ & $4.79(21.3)$ & $1.81(8.01)$ & $17.63(78.46)$ & $5.11(22.74)$ & 22.47 \\
5 & $34.59(49.40)$ & $13.32(19.02)$ & $6.37(9.09)$ & $54.27(77.50)$ & $15.74(22.47)$ & 70.02 \\
8 & $61.32(49.20)$ & $23.05(18.49)$ & $12.21(9.79)$ & $96.63(77.53)$ & $28.02(22.48)$ & 124.63 \\
10 & $62.24(49.70)$ & $20.81(16.62)$ & $14.02(11.19)$ & $97.08(77.52)$ & $28.15(22.47)$ & 125.23 \\
15 & $96.62(49.70)$ & $29.38(15.11)$ & $24.69(12.70)$ & $150.70(77.52)$ & $43.70(22.48)$ & 194.40 \\
20 & $158.25(49.40)$ & $50.4515 .75)$ & $39.63(12.37)$ & $248.33(77.52)$ & $72.01(22.48)$ & 320.34 \\
45 & $276.14(50.69)$ & $85.06(15.61)$ & $61.09(11.21)$ & $422.25(77.51)$ & $122.45(22.48)$ & 544.70 \\
85 & $607.97(52.60)$ & $165.28(14.30)$ & $122.52(10.60)$ & $896.00(77.51)$ & $259.84(22.48)$ & 1155.84 \\
\hline
\end{tabular}

\subsection{Relationship between Tree Age and Allometric Parameters}

Table 2 lists means and standard deviations of all the biometric parameters of the eight age groups examined. Tree age is used as the independent variable to predict the changes of biometric parameters with time. We applied several equations to select an appropriate growth model. Logarithmic and nonlinear exponential equations proposed by Peper et al. (2001a, 2001b) were first tested as these equations showed a good prediction in other environments. The logarithmic regression model was therefore applied to predict DBGU, tree volume, tree height and PBG X NPB from age:

$$
\mathrm{Y}=\mathrm{a} \ln (\mathrm{X})-\mathrm{b}
$$

The summary of the best predictive growth models is presented in Figures 2a-2d. These relationships showed that allometric parameters were significantly related with age of the trees. The tree height was correlated better with age of tree $\left(R^{2}=0.795\right)$ followed by DBGU $\left(R^{2}=0.726\right)$, tree volume $\left(R^{2}=0.644\right)$ and $P B G \times N P B\left(R^{2}=\right.$ $0.563)$. 
Table 2. Means and standard deviations of the biometric parameters of the different age trees examined in grafted mangos

\begin{tabular}{|c|c|c|c|c|c|c|c|c|c|c|c|c|}
\hline \multirow{2}{*}{ Age } & \multicolumn{2}{|c|}{ DBGU (cm) } & \multicolumn{2}{|c|}{ Tree volume $\left(\mathrm{m}^{-3}\right)$} & \multicolumn{2}{|c|}{ Tree height (m) } & \multicolumn{2}{|c|}{$\mathrm{PBG} \times \mathrm{NPB}$} & \multicolumn{2}{|c|}{$\mathrm{ABG}(\mathrm{kg})$} & \multicolumn{2}{|c|}{ Below ground biomass $(\mathrm{kg})$} \\
\hline & Mean & SD & Mean & SD & Mean & SD & Mean & SD & Mean & SD & Mean & SD \\
\hline 3 & 6.63 & 1.96 & 20.55 & 8.22 & 1.67 & 0.38 & 11.31 & 6.06 & 17.63 & 13.58 & 5.11 & 3.94 \\
\hline 5 & 11.87 & 1.18 & 47.97 & 12.23 & 2.60 & 0.57 & 20.80 & 8.13 & 54.27 & 10.67 & 15.74 & 3.09 \\
\hline 8 & 14.73 & 0.72 & 62.17 & 14.84 & 2.83 & 0.62 & 35.22 & 14.84 & 96.63 & 8.95 & 28.02 & 14.20 \\
\hline 10 & 15.67 & 3.58 & 77.45 & 27.79 & 3.23 & 0.76 & 25.04 & 10.04 & 97.08 & 45.95 & 28.15 & 13.32 \\
\hline 15 & 23.43 & 12.13 & 191.87 & 126.37 & 4.38 & 1.48 & 44.16 & 22.6 & 150.70 & 84.04 & 43.70 & 24.37 \\
\hline 20 & 24.73 & 6.26 & 227.48 & 60.49 & 4.83 & 0.78 & 63.72 & 9.46 & 248.33 & 47.50 & 72.01 & 13.78 \\
\hline 45 & 64.74 & 11.97 & 753.55 & 309.21 & 8.25 & 1.44 & 115.58 & 71.39 & 422.25 & 243.81 & 122.45 & 70.71 \\
\hline 85 & 105.73 & 8.10 & 1072.11 & 169.08 & 11.44 & 1.29 & 252.70 & 46.33 & 896.00 & 138.59 & 259.84 & 40.19 \\
\hline
\end{tabular}

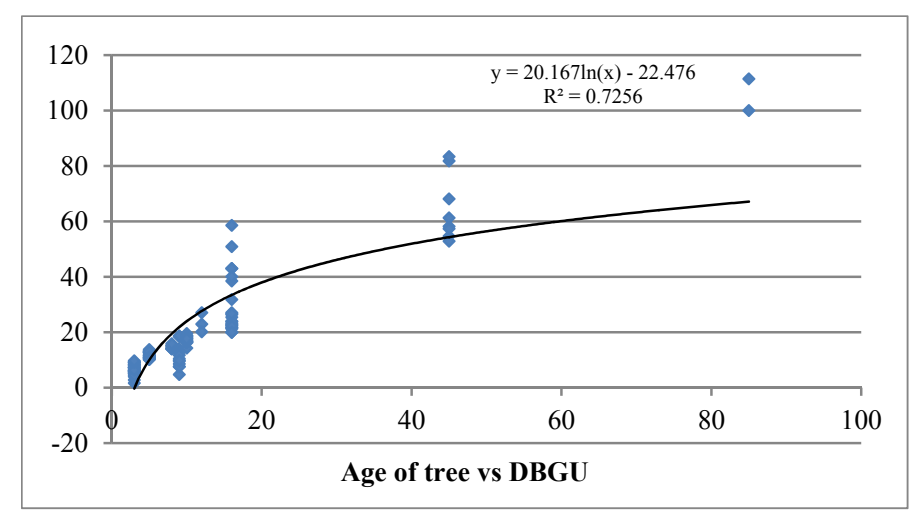

Figure 2a. Age of tree and diameter below graft union (DBGU)

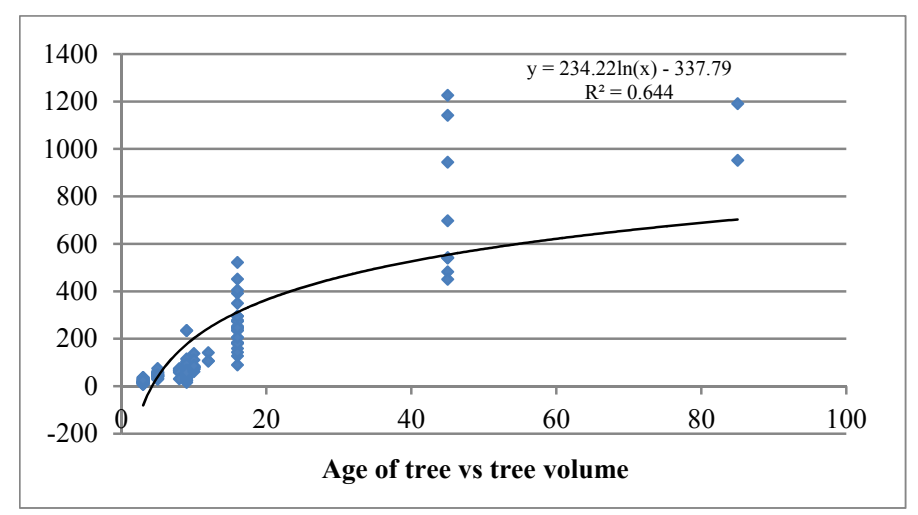

Figure $2 \mathrm{~b}$. Age of tree and tree volume 


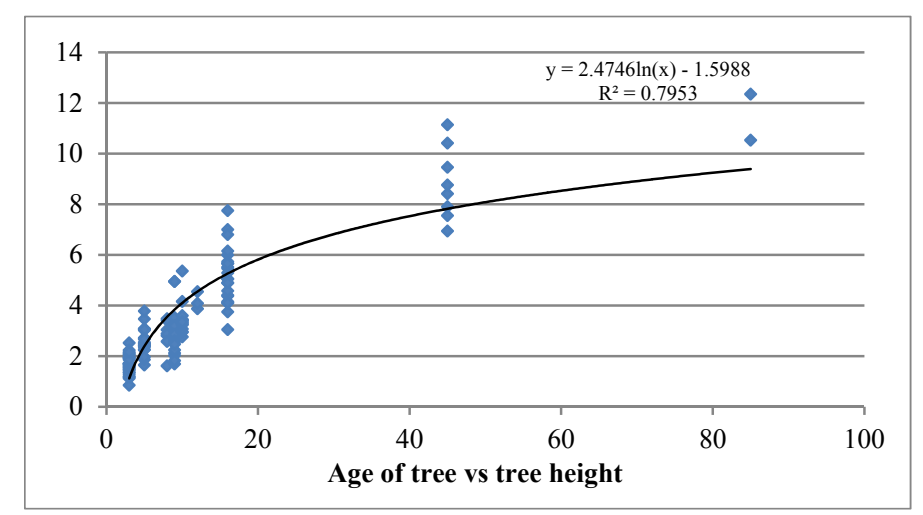

Figure 2c. Age of tree and tree height

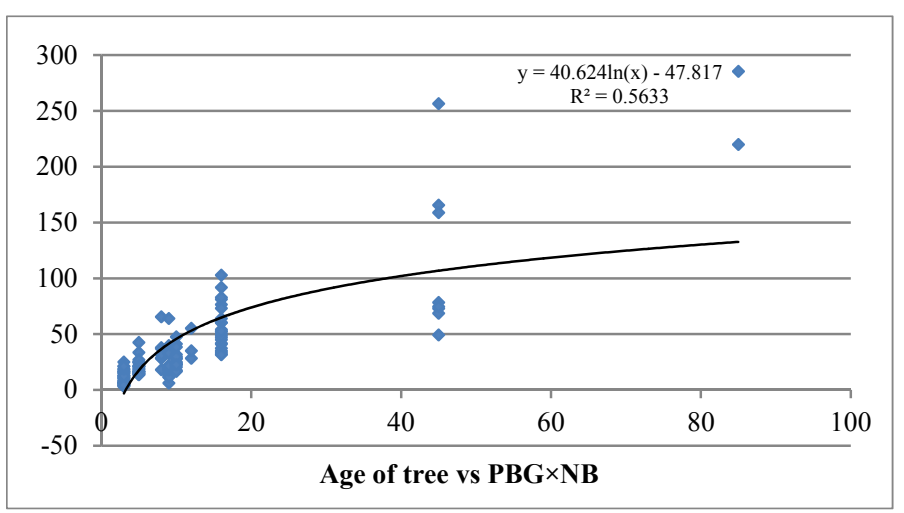

Figure $2 \mathrm{~d}$. Age of tree and primary branch girth $(\mathrm{PBG}) \times$ number of primary branches $(\mathrm{NPB})$

\subsection{Biomass Expansion Factor (BEF)}

The BEF of mango is presented in Table 3. BEFs are needed as a complement of growth models that do not include biomass predictions. In spite of the fact that the BEFs vary with the phase of stand development, constant BEFs are applied in forestry and agro-forestry studies (Löwe et al., 2000; Lehtonen et al., 2007). But to reduce the uncertainty associated with the use of BEFs for biomass estimation, we estimated the BEF of different age groups as the ratio of the biomass to the volume, resulting in a dimensional variable and expressed in $\mathrm{Mg} \mathrm{m}^{-3}$. The BEF varied with age. Initially the BEF was very high followed by a decreasing phase and finally a steady phase. The BEF increased from $0.904\left(\mathrm{Mg} \mathrm{m}^{-3}\right)$ in third year, increased gradually to $1.63\left(\mathrm{Mg} \mathrm{m}^{-3}\right)$ at $8^{\text {th }}$ year. Then the BEF started declining gradually and reached $1.12\left(\mathrm{Mg} \mathrm{m}^{-3}\right)$ at age 20. The BEF by and large attained stability beyond 20 years and attained $0.45\left(\mathrm{Mg} \mathrm{m}^{-3}\right)$ at $85^{\text {th }}$ year. Similar observations were made by several authors (e.g. Brown, 2002; Jalkanen et al., 2005; Lehtonen et al., 2007; Tobin \& Nieuwenhuis, 2007) in other species. These reports support the findings concerning resource allocation during the growth process: 
Table 3. Biomass expansion factor of grafted mango

\begin{tabular}{llll}
\hline \multirow{2}{*}{ Age } & \multicolumn{3}{c}{$\mathrm{BEF}\left(\mathrm{Mg} \mathrm{m}^{-3}\right)$} \\
\cline { 2 - 4 } & Range & Mean & SD \\
\hline 3 & $0.37-2.36$ & 0.904 & 0.523 \\
5 & $0.73-1.81$ & 1.18 & 0.341 \\
8 & $0.96-3.03$ & 1.63 & 0.795 \\
10 & $0.42-1.76$ & 1.30 & 0.50 \\
15 & $0.40-2.37$ & 1.23 & 0.410 \\
20 & $0.91-1.37$ & 1.12 & 0.233 \\
45 & $0.45-0.77$ & 0.55 & 0.155 \\
85 & $0.27-1.04$ & 0.46 & 0.264 \\
Mean & $0.25-3.03$ & 1.047 & \\
\hline
\end{tabular}

\subsection{Relation between Total Aboveground Biomass and Below Ground Biomass (R)}

A good estimates of root biomass, based on the measured above ground biomass and tree age can be obtained by comparing models developed for the purpose.

The average ratio of above- belowground biomass (root:shoot) recorded in this study was found to be 0.291 . In a review of the literature, Cairns et al. (1997) reported a mean R ratio of 0.26 . Our estimated mean R ratio is slightly above this. The root excavation area and depth chosen for grafted mangoes could have resulted in this slight overestimation of the root biomass and, therefore, lead to a higher reported $\mathrm{R}$ ratio. Ideally, in orchard crops the area excavated should represent the drip circle area occupied by the tree, which would be equivalent to tree spacing in orchards. Further the depth of roots was relatively more in this case (Figure 3). The trees were spaced at $10 \mathrm{~m}$ in the study site, and the excavation of roots was done in circular manner covering the drip circle of the trees unlike square shape excavation done in other cases. This might be one of the reasons for the observed higher R in this study.

In Sitka spruce the root diameter decreased rapidly in the first $1 \mathrm{~m}$ from the tree stumps and about $80 \%$ of the root biomass was found in this first $1 \mathrm{~m}$ from the tree stem (Deans, 1981). In this study also similar pattern was observed and that almost $80 \%$ of the total root biomass was concentrated in the first $1 \mathrm{~m}$ from the tree stumps. The error associated with the chosen excavation area in the drip circle of the trees was considered to be relatively small as the measurements made in this study suggests that root biomass stock would appear to reduce exponentially with the distance from the tree stump. IPCC GPG (Penman et al., 2004) reported the mean default value of $R$ as 0.32 with a range of $0.24-0.50$ for trees with aboveground biomass stock of 50-150 tones dry weight ha ${ }^{1}$. Further the $\mathrm{R}$ ratio decreases with an increasing aboveground biomass. Our work suggests that the $\mathrm{R}$ values in this stand are fairly uniform with age and the aboveground biomass stock measured fell within the range reported by Penman et al. (2004) and Cairns et al. (1997).

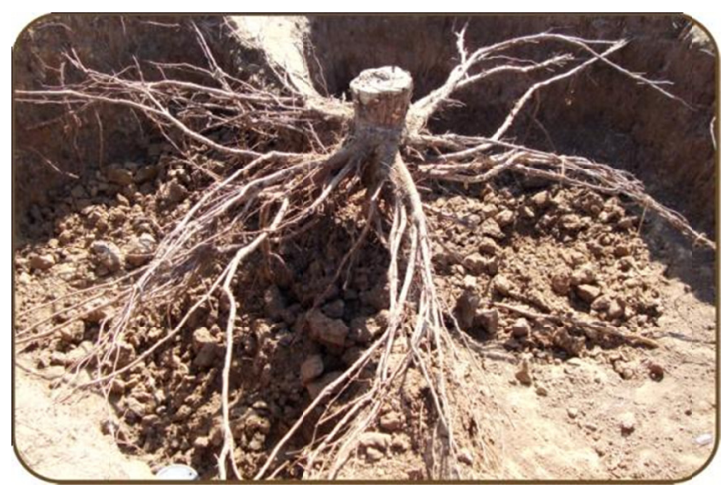

A

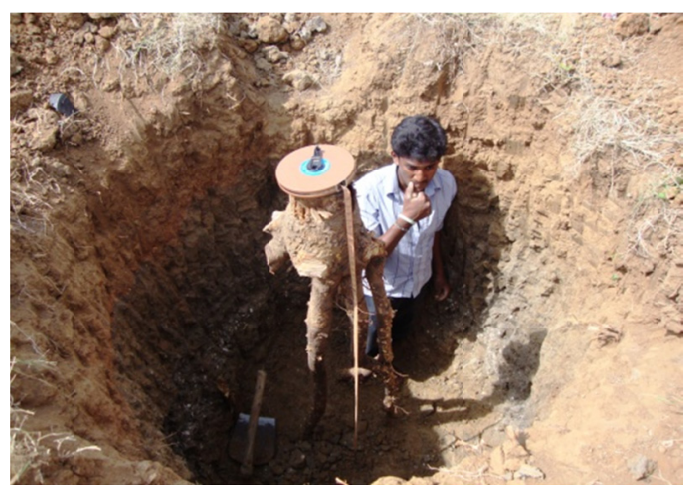

$\mathrm{B}$

Figure 3. Showing root excavation in the drip circle (A) circular excavation and (B) profile excavation 


\subsection{Biomass Estimation}

Use of height-diameter relationships is very common in most allometric equations and in dicotyledonous tree species these are quite similar and have a slope very close to unity and may differ most among larger trees. This is true with mangos grown from seeds but not so in case of commercially grown grafted trees for fruit purpose.

A basic scatter plot examination was conducted while analysing the data. The field and laboratory data and all calculations were verified again and retained only those correct data remained in the data set. We opted for use of three forms of models viz., power model $\left(\mathrm{Y}=\mathrm{aX} \mathrm{X}^{\mathrm{b}}\right)$, logistic model $\left(\mathrm{Y}=\mathrm{a} /\left(1+\mathrm{be}^{-0.042 \mathrm{x}}\right)\right)$ and Gompertz model $(\mathrm{Y}$ $\left.=\mathrm{a} \times \exp \left(\mathrm{be}^{-\mathrm{x}}\right)\right)$ for allometric equations. Where, $\mathrm{Y}=$ biomass of tree and $\mathrm{a}$ and $\mathrm{b}$ are scaling factors (Table 4$)$. As already mentioned the dimensions used were DBGU, Tree height, Tree volume and PBG $\times$ NPB.

Table 4. Allometric equations for estimation of grafted mango above ground biomass

\begin{tabular}{llll}
\hline S.No. & Variables & Model & $\mathbf{R}^{2}$ values \\
\hline $\begin{array}{l}\text { 1. } \text { Power Model: } \\
\text { (1) }\end{array}$ & AGB vs DBGU & $\mathrm{Y}=2.93 \mathrm{X}^{1.22}$ & 0.902 \\
$(2)$ & AGB vs TREE VOLUME & $\mathrm{Y}=1.86 \mathrm{X}^{0.85}$ & 0.855 \\
$(3)$ & AGB vs TREE HEIGHT & $\mathrm{Y}=9.54 \mathrm{X}^{1.8}$ & 0.864 \\
$(4)$ & AGB vs PBG $\times$ NPB & $\mathrm{Y}=2.886 \mathrm{X}^{1.039}$ & 0.971 \\
\hline 2. Logistic Model: & & \\
$(1)$ & AGB vs DBGU & $\mathrm{Y}=1159.61 /\left(1+24.22 \mathrm{e}^{-0.042}\right)$ & 0.879 \\
$(2)$ & AGB vs TREE VOLUME & $\mathrm{Y}=850.47 /\left(1+13.66 \mathrm{e}^{-0.004}\right)$ & 0.838 \\
$(3)$ & AGB vs TREE HEIGHT & $\mathrm{Y}=1394.252 /\left(1+54.05 \mathrm{e}^{-0.376}\right)$ & 0.865 \\
$(4)$ & AGB vs PPG $\times$ NPB & $\mathrm{Y}=869.977 /\left(1+19.853 \mathrm{e}^{-0.027}\right)$ & 0.942 \\
\hdashline 3. Gompertz & Model: & & \\
$(1)$ & AGB vs DBGU & $\mathrm{Y}=1777.42 \times \exp \left(-3.955 \mathrm{e}^{-0.017}\right)$ & 0.89 \\
$(2)$ & AGB vs TREE VOLUME & $\mathrm{Y}=1028.03 \times \exp \left(-3.054 \mathrm{e}^{-0.002}\right)$ & 0.846 \\
$(3)$ & AGB vs TREE HEIGHT & Not suitable fit & - \\
$(4)$ & AGB vs PPG $\times$ NPB & $\mathrm{Y}=995.91 \times \exp \left(-3.63 \mathrm{e}^{-0.013}\right)$ & 0.964 \\
\hline
\end{tabular}

The equations generally fitted the data well, and in most cases more than $50 \%$ of the observed variation in biomass was explained by PBG $\times$ NPB. All equations were statistically significant $(p<0.05)$ for both scaling parameters, $a$ and $b$. Based on the $\mathrm{R}^{2}$ values the best fit model for estimation of above ground biomass of grafted mango trees is a power model using $\mathrm{PBG} \times \mathrm{NPB}$ as the best dimension:

$$
\mathrm{Y}=2.886 \mathrm{X}^{1.039}, \mathrm{R}^{2}=0.971
$$

A plot between estimated AGB and predicted AGB using this equation is presented in Figure 4. There is a good agreement between the observed and the predicted biomass using this equation. 


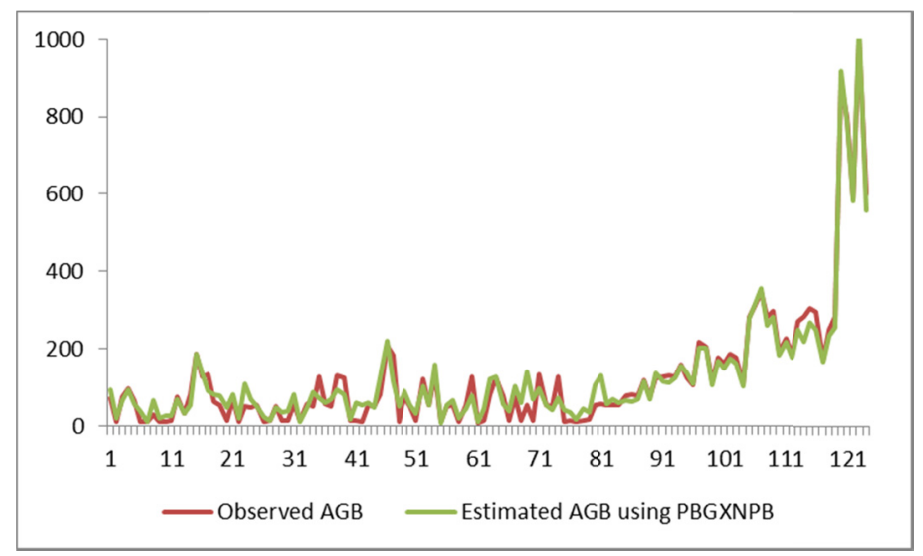

Figure 2. Estimated and predicted above ground biomass (AGB) using primary branch girth $(\mathrm{PBG}) \times$ number of primary branches $(\mathrm{NPB})\left(\mathrm{Y}=2.886 \mathrm{X}^{1.039}\right)$

Published information shows that most equations relate tree biomass to diameter or diameter coupled with height. A review of equations developed for 65 species by Ter-Mikaelian and Korzukhin (1997) and Zianis and Mencuccini (2004) showed that in most cases tree diameter is the single metric most commonly used for tree allometry. These equations mostly deal with forest species and addressed silviculture issues and specifically the timber part. Very few addressed the mono-cropped tropical fruit trees like mango from the perspective of carbon sequestration. Almost all of these relationships, whether intended for application to particular purpose, particular species, climate-related biomes, or bio-geo-graphical regions are based on the allometric equation. These equations are theoretically very sound (Pearsall, 1927; Causton, 1985; Niklas, 1994; West et al., 1997), but its application to grafted fruit trees is problematic for two reasons: first, the complicated branching of grafted plants starting from just above the graft union and second, the DBH a very common parameter used in published allometric equations of either mango or related species is not possible to measure in grafted trees because of the branching beginning just above ground level, above the graft union. Hence the equation developed specifically for the grafted plants in our study will be of immense use in working out the biomass of orchards and to work out the carbon sequestration of mangos.

\section{Conclusions}

Grafted mango trees of commercial orchards require independent allometric equation for estimation of tree biomass. The equations were hence developed using parameters other than $\mathrm{DBH}$. The root to shoot ration also differed from those reported for forest trees. The BEF by and large attained stability beyond 20 years. The equations developed using PBG $\times$ NPB fitted the data well, and was statistically significant. There was a good agreement between the observed and the predicted biomass using this equation. Additionally, comparisons between existing national biomass estimates, developed using a default allometric equation and BEF approach, and those generated from the new equation developed under this work, are needed to focus on identifying variables that substantially contribute to uncertainty in the $\mathrm{C}$ stock estimates of mango fruit orchards.

\section{Acknowledgements}

The financial support received from ICAR-National Innovations on Climate Resilient Agriculture (NICRA) is gratefully acknowledged.

\section{References}

Araujo, T. M., Higuchi, N., \& Andrade de CarvalhoJunior, J. (1999). Comparison of formulae for biomass content determination in a tropical rain forest site in the state of Para, Brazil. For. Ecol. Manage., 117, 43-52. http://dx.doi.org/10.1016/S0378-1127(98)00470-8

Avery, T. E., \& Burkhart, H. (2002). Forest Measurements. McGraw-Hill Companies Inc., New York.

Brown, S. (1997). Estimating biomass and biomass change of tropical forests: A primer. FAO Forestry Paper 134, Rome.

Brown, S. (2002). Measuring carbon in forests: Current status and future challenges. Environ Pollut, 116, 363-372. http://dx.doi.org/10.1016/S0269-7491(01)00212-3 
Brown, S., Gillespie, A. J. R., \& Lugo, A. E. (1989). Biomass estimation methods for tropical forests with applications to forest inventory data. For. Sci., 35, 881-902.

Cairns, M. A., Brown, S., Helmer, E. H., \& Baumgardner, G. A. (1997). Root biomass allocation in the world's upland forests. Oecologia, 111, 1-11. http://dx.doi.org/10.1007/s004420050201

Causton, D. R. (1985). Biometrical, structural and physiological relationships among tree parts. In M. G. R. Cannell \& J. E. Jackson (Eds.), Trees as Crop Plants. Institute of Terrestrial Ecology (pp. 137-159). Huntington, UK.

Chambers, J. Q., dos Santos, J., Ribeiro, R. J., \& Higuchi, N. (2001). Tree damage, allometric relationships, and above-ground net primary production in central Amazon forest. For. Ecol. Manage., 152, 73-84. http://dx.doi.org/10.1016/S0378-1127(00)00591-0

Chave, J., Andalo, C., Brown, S., Cairns, M. A., Chambers, J. Q., Eamus, D., .. Yamakura, T. (2005). Tree allometry and improved estimation of carbon stocks and balance in tropical forests. Oecologia, 145, 87-99. http://dx.doi.org/10.1007/s00442-005-0100-x

Dawkins, H. C. (1961). Estimating total volume of some Caribbean trees. Caribbean Forester, 22, 62-63.

Deans, J. D. (1981). Dynamics of coarse root production in a young plantation of Piceasitchensis. Forestry, 54, 139-155. http://dx.doi.org/10.1093/forestry/54.2.139

Enejil, I. S., Obinna, O., \& Azua, E. T. (2014). Sequestration and carbon storage potential of tropical forest reserve and tree species located within benuestate of Nigeria. Journal of Geoscience and Environment Protection, 2, 157-166. http://dx.doi.org/10.4236/gep.2014.22022

Jalkanen, A., Mäkipää, R., Ståhl, G., Lehtonen, A., \& Petersson, H. (2005). Estimation of the biomass stock of trees in Sweden: Comparison of biomass equations and age-dependent biomass expansion factors. Ann. For. Sci., 62, 845-851. http://dx.doi.org/10.1051/forest:2005075

Ketterings, Q. M., Coe, R., van Noordwijk, M., Ambagu, Y., \& Palm, C. A. (2001). Reducing uncertainty in use of allometric biomass equations for predicting above-ground tree biomass in mixed secondary forests. For. Ecol. Manage., 146, 199-202. http://dx.doi.org/10.1016/S0378-1127(00)00460-6

Lehtonen, A., Cienciala, E., Ttatarinov, F., \& Mäkipää, R. (2007). Uncertainty estimation of biomass expansion factors for Norway spruce in the Czech Republic. Ann. For. Sci., 64, 133-140. http://dx.doi.org/10.1051/forest:2006097

Lowe, H., Seufert, G., \& Raes, F. (2000). Comparison of methods used within member states for estimating $\mathrm{CO}_{2}$ emissions and sinks according to UNFCCC and EU monitoring mechanisms: forest and other wooded land. Biotechnol Agron Soc Environ, 4, 315-319.

Niklas, K. J. (1994). Plant Allometry: The Scaling of Form and Process. University of Chicago Press, Chicago, USA.

Normand, F., \& Lauri, P.-É. (2012). Assessing allometric models to predict vegetative growth of mango (Mangifera indica L., Anacardiaceae) at the current-year branch scale. American Journal of Botany, 99(3), 425-437. http://dx.doi.org/10.3732/ajb.1100249

Normand, F., Bissery, C., Damour, G., \& Lauri, P.-É. (2008). Hydraulic and mechanical stem properties affect leaf-stem allometry in mango cultivars. New Phytologist, 178, 590-602. http://dx.doi.org/10.1111/j.14 69-8137.2008.02380.x

Ogawa, H., Yoda, K., Ogino, K., \& Kira, T. (1965). Comparative ecological studies on three main types of forest vegetation in Thailand. II. Plant Biomass. Nature Life Southeast Asia, 4, 49-80.

Overman, J. P. M., Witte, H. J. L., \& Saldarriaga, J. G. (1994). Evaluation of regression models for above-ground biomass determination in Amazon rainforest. J. Trop. Ecol., 10, 207-218. http://dx.doi.org/10.1017/S026646 7400007859

Pearsall, W. H. (1927). Growth studies. VI. on the relative sizes of growing plant organs. Ann. Bot., 41, $549-556$.

Penman, J., Gytarsky, M., Hiraishi, T., Krug, T., Kruger, T., Pipatti, D., ... Wagner, F. (Eds). (2004). IPCC good practice guidance for land use, land use change and forestry. Institute for Global Environmental Strategies (IGES), Hayama, Kanagawa, Japan.

Peper, P. J., McPherson, E. G., \& Mori, S. M. (2001a). Predictive equations for dimensions and leaf area of coastal southern California street trees. Journal of Arboriculture, 27, 169-180. 
Peper, P. J., McPherson, E. G., \& Mori, S. M. (2001b). Equations for predicting diameter, height, crown width and leaf area of San Joaquin Valley street trees. Journal of Arboriculture, 27, 306-317.

Seber, G. A. F., \& Wild, C. J. (1989). Nonlinear Regression. John Wiley and Sons, New York. http://dx.doi.org/10.1002/0471725315

Smith, W. B., \& Brand, G. J. (1983). Allometric biomass equations for 98 species of herbs, shrubs, and small trees. Research note NC-299 (p. 8). USDA Forest Service, North Central Forest Experiment Station, St. Paul, MN, USA.

Soares, P., \& Tome, M. (2012). Biomass expansion factors for Eucalyptus globulus stands in Portugal. Forest Systems, 21, 141-152. http://dx.doi.org/10.5424/fs/2112211-12086

Soares, P., \& Tome, M. (2012). Biomass expansion factors for Eucalyptus globulusstands in Portugal. Forest Systems, 21, 141-152. http://dx.doi.org/10.5424/fs/2112211-12086

Specht, A., \& West, P. W. (2003). Estimation of biomass and sequestered carbon on farm forest plantations in northern New South Wales, Australia. Biomass Stradbroke Island. Aust. J. Bot., 25, 171-191.

Ter-Mikaelian, M. T., \& Korzukhin, M. D. (1997). Biomass equations for sixty-five North American tree species. For Ecol Manage, 97, 1-24. http://dx.doi.org/10.1016/S0378-1127(97)00019-4

Tobin, B., \& Nieuwenhuis, M. (2007). Biomass expansion factors for Sitka spruce (Piceasitchensis (Bong). Carr.) in Ireland. Eur J For Res, 126, 189-196. http://dx.doi.org/10.1007/s10342-005-0105-3

Venugopalan, R., \& Shamasundaran, K. S. (2003). Nonlinear regressions: A realistic modeling approach in horticultural crop research. J. of Indian Society of Agrl. Statistics, 56, 1-6.

West, G. B., Brown, J. H., \& Enquist, B. J. (1997). A general model for the origin of allometric scaling laws in biology. Science, 276, 122-126. http://dx.doi.org/10.1126/science.276.5309.122

Westman, W. E., \& Rogers, R. W. (1977). Biomass and structure of a subtropical eucalypt forest, North Stradbroke Island. Aust. J. Bot., 25, 171-191. http://dx.doi.org/10.1071/BT9770171

Zianis, D., \& Mencuccini, M. (2004). On simplifying allometric analyses of forest biomass. For Ecol Manage, 187, 311-332. http://dx.doi.org/10.1016/j.foreco.2003.07.007

\section{Copyrights}

Copyright for this article is retained by the author(s), with first publication rights granted to the journal.

This is an open-access article distributed under the terms and conditions of the Creative Commons Attribution license (http://creativecommons.org/licenses/by/4.0/). 